\title{
HEMODYNAMIC AND BISPECTRAL CHANGES DURING PIN INSERTION IN CRANIOTOMY - EFFECT OF LOCALLY INFILTRATED BUPIVACAINE
}

\author{
Vesna Durnev ${ }^{1}$, Marija Soljakova ${ }^{1}$, Venko Filipce ${ }^{2}$, Maja Mojsova Mijovska ${ }^{1}$, Marina Temelkovska Stevanovska ${ }^{1}$ \\ ${ }^{1}$ Clinic of Traumatology, Orthopedics, Anesthesia, Reanimation, Intensive care and Emergency at Medical School, \\ University "St. Cyril and Methodius", Skopje, R. of Macedonia \\ ${ }^{2}$ University Clinic of Neurosurgery at Medical School, University "St. Cyril and Methodius", Skopje, R. of Macedonia
}

Corresponding author: Vesna Durnev. University Clinic of Traumatology, Orthopedics, Anaesthesia, Reanimation, Intensive care and Emergency at Medical School, University "St. Cyril and Methodius", Skopje, R. of Macedonia, Vodnjanska st. 17, Skopje, R. of Macedonia; Tel: +38972 238506; E-mail: vesna.durnev@gmail.com

\section{ABSTRACT}

Introduction Cranial pins insertion is a method for head stabilization and together with the scalp incision is one of the biggest noxious stimulus associated with arousal and rapid increase of the blood pressure leading to pathological increase of the intracranial pressure. The aim of this investigation is to study the superiority of the locally infiltrated anesthetic bupivacaine just before the skull pin insertion and the scalp incision in craniotomy under general anesthesia.

Methods In the study thirty patients of both genders aged 24-72 years were included. They were categorized as ASA 1 and 2 and divided into two group of 15 patients each, group B (bupivacaine) and group $\mathrm{S}$ (saline). We recorded the bispectral (BIS) index, the mean arterial pressure (MAP) and the pulse rate $(\mathrm{PR})$ in five time intervals:

t $0-2$ min before pin insertion; $t$ 1-2 min after pin insertion; $t$ 2-5 min after; $t$ 3-10min after and $t$ 4-15 min after.

Results Significant difference $\mathrm{p}<0.05$ was achieved in group $\mathrm{S}$ for all three followed parameters: blood pressure, heart rate and bispectral index. The difference is present in all four time intervals compared to the initial one before the pin insertion. With further analysis it was demonstrated that the investigated BIS index participates the most in the overall significance in group F.

Conclusion The scalp infiltration with local anesthetic bupivacaine results with stable hemodynamic parameters and stable intracranial pressure during the painful procedures as craniotomy.

Key words: cranial pin, local infiltrative anesthesia, hemodynamics, bispectral index, bupivacaine

\section{INTRODUCTION}

The maintenance of the normal values of the arterial blood pressure and the control of the anesthesia depth during the perioperative period is one of the most important issues in the neuroanaesthesia, especially when we have patients with cerebral vascular changes and tumors. During the perioperative period the mean arterial pressure (MAP) values may increase or decrease excessively. A hazardous decrease in the arterial pres- sure, regardless of the underlying cause, leads to cerebral hypoperfusion and possible brain damage if this hypoperfusion lasts too long. On the other hand, any kind of nociceptive stimulation in an insufficiently anesthetized patient is associated with a sudden increase in the arterial blood pressure, which carries the risk of aneurysm rupture or a rapid increase in the intracranial pressure $[1,2]$.

The hemodynamic response as sudden tachycardia and hypertension can occur even after an adequate proper depth of general anesthesia. This 
stress response is detrimental in patients with intracranial pathology [3].

The insertion of cranial pins for head stabilization is a method for head stabilization in elective craniotomy and together with skin incision is one of the prominent noxious stimuli. They induce in insufficiently anesthetized patients significant hemodynamic response, increased stress hormones and in patients with impaired autoregulation may lead to increased intracranial pressure $[4,5]$.

The determination of the bispectral index (BIS) is a method which has gained popularity because it reflects the hypnotic and anesthetic depth. The BIS index is a measure derived from the processed electroencephalogram (EEG) data $\left.{ }^{6}\right]$. The BIS index has been shown to be superior to the other processed EEG parameters in assessing the depth of anesthesia and sedation $[7,8]$. A BIS value of 40-65 is suitable for anesthesia [ $\left.{ }^{9}\right]$. The BIS index can be also used as a predictor of patient's response to nociceptive stimulus under anesthesia and it has decreased the incidence of intraoperative awareness $[10,11]$.

These detrimental hemodynamic and awareness changes can be prevented by infiltration of the scalp with local anesthetic [12] or by skull block prior to pin placement [13]

We hypothesized that the values of the BIS index and hemodynamic parameters would increase when skull pins are inserted and skin incision is performed although the anesthetic depth is adequate enough. It would remain unchanged when patients received local anesthetic bupivacaine infiltration of the scalp, which blocks the strong nociceptive stimuli followed with stable perioperative patient condition.

\section{OBJECTIVE}

The objective of the study is to examine the superiority of the locally infiltrated anesthetic bupivacaine at the place of the pin insertion and the skin incision in preventing pain stimulation in patients with craniotomy measured through the changes in the bispectral index (BIS) and the hemodynamic parameters as mean arterial pressure and heart rate.

\section{MATERIALS AND METHODS}

The study was designed as prospective, control randomized research. This randomized prospective trial was conducted at the University
Clinic of Traumatology, Orthopedics, Anesthesia, Reanimation, Intensive care and Emergency and the University Clinic of Neurosurgery at Medical School, University "St. Cyril and Methodius", Skopje, Republic of Macedonia, in a period of six months (January 2016 till June 2016).

After obtaining the written information consent from each patient, we enrolled a total of thirty patients of both genders, aged 20-70 years ASA physical status I and II, undergoing elective craniotomy.

Criteria for exclusion were patients with uncontrolled hypertension, patients undergoing emergency surgery, intracranial aneurysm surgery, those having significant cardiac, pulmonary, renal or hepatic disease, those having contraindication to beta blockers, or taking treatment that can affect hemodynamic parameters. Criterion for exclusion is the already known hypersensitivity to local anesthetic bupivacaine.

All patients were premedicated with diazepam $5 \mathrm{mg}$ orally the night before the day of surgery and on the morning of surgery. In the operating room, a BIS sensor (Covidien) was attached to the forehead and the monitor was set to generate a value every $15 \mathrm{~s}$. The routine monitoring consisted of an electrocardiogram (ECG), end tidal $\mathrm{CO}^{2}$, pulse oximetry, invasive blood pressure (IBP) and heart rate measurement.

The patients were induced with fentanyl $2 \mu$ / $\mathrm{kg}$, propofol $1.5-2 \mathrm{mg} / \mathrm{kg}$ and rocuronium in dose of $0.6 \mathrm{mg} / \mathrm{kg}$. Ventilation was maintained with a tidal volume of $6-8 \mathrm{ml} / \mathrm{kg}$ and respiratory frequency of $12-15 / \mathrm{min}$. Anesthesia was maintained with continuous remifentanil infusion and isoflurane $1 \%-2 \%$ in mixture of $50 \%$ air/oxygen. The depth of the anesthesia was maintained within the BIS index value of 40-60.

After the normalization of the hemodynamic effects of the tracheal intubation (approximately 5 min after intubation), the patients were randomized in two groups. The first group (Group B) of 15 patients received $20 \mathrm{ml} 0.25 \%$ bupivacaine local anesthetic infiltrated at the place of the pin insertion and the skin incision. The second group (Group S) consisted of 15 patients same as the first one who received $20 \mathrm{ml}$ saline scalp infiltration 2 to 5 minutes before the pin insertion and the skin incision. We followed the changes in the BIS index value and the hemodynamic parameters as the mean arterial pressure and heart rate using recorded values before the pin insertion and the skin incision in time ( $\mathrm{t} 0)$ and subsequently the regular intervals of $5 \mathrm{~min}(\mathrm{t} 1, \mathrm{t} 2, \mathrm{t} 3, \mathrm{t} 4)$ after the pin insertion for total time of $20 \mathrm{~min}$. 


\section{STATISTICAL ANALYSES}

The data for the continuous variables such as age, HR, MAP and BIS index were expressed as mean with SD. The comparison of the changes over time between the groups was carried out by using the independent Student's $t$-test and we used analysis of variance (ANOVA) to see the significance in comparing t0 with other time intervals for all three variables in two groups.

The post hoc test of Tukey for group S (difference between $t 0$ and other time intervals) was also used to reveal the variable that contributes the most in the overall statistically significant result.

All statistical analyses were carried out with $5 \%$ level of significance, and $P<0.05$ was considered as significant difference.

\section{RESULTS}

The investigation consisted of 30 patients divided in two groups, each of 15 patients, group B

Table 1. Gender prevalence

\begin{tabular}{|l|c|c|c|c|}
\hline & Group B & Percentage & Group S & Percentage \\
\hline M & 9 & 60.00000 & 10 & 66.66667 \\
\hline F & 6 & 40.00000 & 5 & 33.33333 \\
\hline Total & 15 & 100.0 & 15 & 100.0 \\
\hline
\end{tabular}

and group $\mathrm{S}$. The demographic data are displayed in Table 1 as percentage and in Table 2 as mean value $\pm \mathrm{SD}$.

The gender structure of the examined people in either group is presented as percentage in Table 1 showing little predominance in males, but the overall difference in the gender distribution of the investigated people is without any significance between two groups.

According to the results presented in Table 2 there is no significant difference in the distribution of the variables as age, weight and height.

In Table 3 the three variables are presented as $\mathrm{MV} \pm \mathrm{SD}$ : mean arterial pressure (MAP), heart rate (HR) and bispectral index (BIS) measured in four time intervals after the pin insertion $\mathrm{t} 1-2$ $\min , \mathrm{t} 2-5 \min , \mathrm{t} 3-10 \mathrm{~min}, \mathrm{t} 4-15 \mathrm{~min}$. There is a significant difference $p<0.05$ between the two groups for all three variables in time intervals t2 and $\mathrm{t} 3$, the significance in time interval $\mathrm{t} 1$ is shown for variables MAP and HR and in time interval t4 is shown for MAP and BIS.

In Table 4 the three variables are shown by comparing values in time interval to related to all following time measurement $\mathrm{t} 1, \mathrm{t} 2, \mathrm{t} 3$ and $\mathrm{t} 4 \mathrm{with}$ the goal to see which time interval contributes the most to the significant difference. For all three variables, time $\mathrm{t} 0$ compared to $\mathrm{t} 1, \mathrm{t} 2, \mathrm{t} 3$ and $\mathrm{t} 4$ shows significant difference in Gr. S.

Table 2. Demographic characteristics

\begin{tabular}{|l|c|c|c|}
\hline Parameter & Group B & Group S & p - value \\
\hline Gender M/F & $9 / 6$ & $10 / 5$ & 0.7034 \\
\hline Age & $52.6 \pm 15.3$ & $58.26 \pm 13.76$ & 0.296738 \\
\hline Weight & $73.2 \pm 15.4$ & $71.06 \pm 8.99$ & 0.636867 \\
\hline Height & $165.8 \pm 10.9$ & $172.13 \pm 9.16$ & 0.723987 \\
\hline
\end{tabular}

Shortcuts: B-Bupivacaine; S - Saline

Table 3. Hemodynamic parameters and BIS index in different time intervals comparing the two groups

\begin{tabular}{|c|c|c|c|c|c|c|c|c|c|}
\hline & \multicolumn{3}{|c|}{ MAP } & \multicolumn{3}{|c|}{ HR } & \multicolumn{3}{|c|}{ BIS } \\
\hline time & $\begin{array}{c}\text { Gr B } \\
6 p=15\end{array}$ & $\begin{array}{c}\text { Gr S } \\
6 p=15\end{array}$ & $\mathrm{p}$ & $\begin{array}{c}\mathrm{Gr} B \\
6 p=15\end{array}$ & $\begin{array}{c}\text { Gr S } \\
6 p=15\end{array}$ & $\mathrm{p}$ & $\begin{array}{c}\text { Gr B } \\
6 p=15\end{array}$ & $\begin{array}{c}\mathrm{Gr} S \\
\sigma p=15\end{array}$ & $\mathrm{p}$ \\
\hline to & $\begin{array}{c}61 \\
\pm 7.7\end{array}$ & $\begin{array}{c}69.6 \\
\pm 16.9\end{array}$ & 0.082974 & $\begin{array}{c}70.3 \\
\pm 14.1\end{array}$ & $\begin{array}{c}68 \\
\pm 15.6\end{array}$ & 0.672267 & $\begin{array}{l}44.4 \\
\pm 4.8\end{array}$ & $\begin{array}{l}44.6 \\
\pm 4.9\end{array}$ & 0.912244 \\
\hline $\mathrm{t} 1$ & $\begin{array}{l}64.26 \\
\pm 7.2\end{array}$ & $\begin{array}{c}96.2 \\
\pm 20.7\end{array}$ & 0.000005 & $\begin{array}{c}74.3 \\
\pm 13.8\end{array}$ & $\begin{array}{c}85.4 \\
\pm 15.7\end{array}$ & 0.049579 & $\begin{array}{r}47,9 \\
\pm 6.3\end{array}$ & $\begin{array}{l}52.4 \\
\pm 6.2\end{array}$ & 0.061110 \\
\hline t2 & $\begin{array}{c}64.53 \\
\pm 7.4\end{array}$ & $\begin{array}{c}97.6 \\
\pm 20.4\end{array}$ & 0.000002 & $\begin{array}{l}72.8 \\
\pm 13\end{array}$ & $\begin{array}{c}87.4 \\
\pm 11.4\end{array}$ & 0.002810 & $\begin{array}{l}46.9 \\
\pm 5.8\end{array}$ & $\begin{array}{c}54 \\
\pm 5.4\end{array}$ & 0.001962 \\
\hline $\mathrm{t} 3$ & $\begin{array}{c}62.46 \\
\pm 7.0\end{array}$ & $\begin{array}{l}97.13 \\
\pm 18.6\end{array}$ & 0.000000 & $\begin{array}{c}72.3 \\
\pm 13.2\end{array}$ & $\begin{array}{l}85.8 \\
\pm 9.8\end{array}$ & 0.003751 & $\begin{array}{l}45.4 \\
\pm 4.4\end{array}$ & $\begin{array}{l}52.3 \\
\pm 4.0\end{array}$ & 0.000120 \\
\hline t4 & $\begin{array}{l}61.3 \\
\pm 6.1\end{array}$ & $\begin{array}{c}86.5 \\
\pm 16.3\end{array}$ & 0.000006 & $\begin{array}{c}71.6 \\
\pm 13.1\end{array}$ & $\begin{array}{c}79.5 \\
\pm 10.1\end{array}$ & 0.076774 & $\begin{array}{l}44.9 \\
\pm 4.6\end{array}$ & $\begin{array}{l}51.3 \\
\pm 4.0\end{array}$ & 0.000398 \\
\hline
\end{tabular}


Table 4. Comparing the values for BIS, MAP and HR (t0/t1; t0/t2; t0/t3;t0/t4)

\begin{tabular}{|l|c|c|c|c|c|c|c|c|}
\hline & SS - Eff. & df - Eff. & MS - Eff. & SS - Err. & df - Err. & MS - Err. & F & p \\
\hline BIS T0 Gr S & 806.800 & 4 & 201.700 & 1757.87 & 70 & 25.1124 & 8.031895 & $\mathbf{0 . 0 0 0 0 2 2}$ \\
\hline MAP & 8593.520 & 4 & 2148.380 & 24531.07 & 70 & 350.4438 & 6.130455 & $\mathbf{0 . 0 0 0 2 7 4}$ \\
\hline HR & 3834.587 & 4 & 958.647 & 11537.60 & 70 & 164.8229 & 5.816224 & $\mathbf{0 . 0 0 0 4 2 3}$ \\
\hline BIS T0 Gr B & 129.520 & 4 & 32.380 & 1960.00 & 70 & 28.0000 & 1.156429 & 0.337539 \\
\hline MAP & 159.387 & 4 & 39.847 & 3565.73 & 70 & 50.9390 & 0.782242 & 0.540523 \\
\hline HR & 129.813 & 4 & 32.453 & 12765.73 & 70 & 182.3676 & 0.177956 & 0.949058 \\
\hline
\end{tabular}

Table 5. Group S BIS t0

\begin{tabular}{|c|c|c|c|c|c|}
\hline & $\{\mathbf{0}\}-\mathbf{M}=\mathbf{4 4 . 6 0 0}$ & $\{\mathbf{1}\}-\mathbf{M}=\mathbf{5 2 . 4 0 0}$ & $\{\mathbf{2}\}-\mathbf{M}=\mathbf{5 4 . 0 0 0}$ & $\{\mathbf{3}\}-\mathbf{M}=\mathbf{5 2 . 3 3 3}$ & $\{\mathbf{3}\}-\mathbf{M}=\mathbf{5 1 . 3 3 3}$ \\
\hline $\mathbf{1}\{\mathbf{0}\}$ & & $\mathbf{0 . 0 0 0 6 9 0}$ & $\mathbf{0 . 0 0 0 1 4 3}$ & $\mathbf{0 . 0 0 0 7 6 6}$ & $\mathbf{0 . 0 0 4 1 4 2}$ \\
\hline $\mathbf{2}\{\mathbf{1}\}$ & $\mathbf{0 . 0 0 0 6 9 0}$ & & 0.905400 & 1.000000 & 0.977248 \\
\hline $\mathbf{3}\{\mathbf{2}\}$ & $\mathbf{0 . 0 0 0 1 4 3}$ & 0.905400 & & 0.891881 & 0.593297 \\
\hline $\mathbf{4}\{\mathbf{3}\}$ & $\mathbf{0 . 0 0 0 7 6 6}$ & 1.000000 & 0.891881 & & 0.982080 \\
\hline $\mathbf{5}\{\mathbf{4}\}$ & $\mathbf{0 . 0 0 4 1 4 2}$ & 0.977248 & 0.593297 & 0.982080 & \\
\hline
\end{tabular}

Table 6. Group S MAP t0

\begin{tabular}{|c|c|c|c|c|c|}
\hline & $\{\mathbf{0}\}-\mathbf{M}=\mathbf{6 9 . 6 6 7}$ & $\{\mathbf{1}\}-\mathbf{M}=\mathbf{9 6 . 2 6 7}$ & $\{\mathbf{2}\}-\mathbf{M}=\mathbf{9 7 . 6 6 7}$ & $\{\mathbf{3}\}-\mathbf{M}=\mathbf{9 7 . 1 3 3}$ & $\{\mathbf{4}\}-\mathbf{M}=\mathbf{8 6 . 5 3 3}$ \\
\hline $\mathbf{1}\{\mathbf{0}\}$ & & $\mathbf{0 . 0 0 2 1 6 0}$ & $\mathbf{0 . 0 0 1 1 2 9}$ & $\mathbf{0 . 0 0 1 4 3 4}$ & 0.110070 \\
\hline $\mathbf{2}\{\mathbf{1}\}$ & $\mathbf{0 . 0 0 2 1 6 0}$ & & 0.999643 & 0.999947 & 0.614597 \\
\hline $\mathbf{3}\{\mathbf{2}\}$ & $\mathbf{0 . 0 0 1 1 2 9}$ & 0.999643 & & 0.999992 & 0.484522 \\
\hline $\mathbf{4}\{\mathbf{3}\}$ & $\mathbf{0 . 0 0 1 4 3 4}$ & 0.999947 & 0.999992 & & 0.533689 \\
\hline $\mathbf{5}\{\mathbf{4}\}$ & 0.110070 & 0.614597 & 0.484522 & 0.533689 & \\
\hline
\end{tabular}

Significant difference $\mathrm{p}<0.05000$ (Tukey HSD тест)

Table 7. Group S HR t0

\begin{tabular}{|c|c|c|c|c|c|}
\hline & $\{\mathbf{0}\}-\mathbf{M}=\mathbf{6 8 . 0 0 0}$ & $\{\mathbf{1}\}-\mathbf{M}=\mathbf{8 5 . 4 6 7}$ & $\{\mathbf{2}\}-\mathbf{M}=\mathbf{8 7 . 4 6 7}$ & $\{\mathbf{3}\}-\mathbf{M}=\mathbf{8 5 . 8 0 0}$ & $\{\mathbf{4}\}-\mathbf{M}=\mathbf{7 9 . 5 3 3}$ \\
\hline $\mathbf{1}\{\mathbf{0}\}$ & & $\mathbf{0 . 0 0 3 5 9 4}$ & $\mathbf{0 . 0 0 0 9 5 2}$ & $\mathbf{0 . 0 0 2 8 8 8}$ & 0.111841 \\
\hline $\mathbf{2}\{\mathbf{1}\}$ & $\mathbf{0 . 0 0 3 5 9 4}$ & & 0.993001 & 0.999995 & 0.712916 \\
\hline $\mathbf{3}\{\mathbf{2}\}$ & $\mathbf{0 . 0 0 0 9 5 2}$ & 0.993001 & & 0.996576 & 0.445385 \\
\hline $\mathbf{4}\{\mathbf{3}\}$ & $\mathbf{0 . 0 0 2 8 8 8}$ & 0.999995 & 0.996576 & & 0.669483 \\
\hline $\mathbf{5}\{\mathbf{4}\}$ & 0.111841 & 0.712916 & 0.445385 & 0.669483 & \\
\hline
\end{tabular}

Significant difference $\mathrm{p}<0.05000$ (Tukey HSD тест)

With post hoc Tukey test in Table 5, 6 and 7 we can see that variable BIS in group S contribute the most in total significant difference.

\section{DISCUSSION}

The scalp is densely innervated with C-fibers [14]. A lot of studies with scalp blocks and skin incision infiltration were done to describe the relief from postoperative pain after craniotomy as in the study of Bloomfield from 1998 and Biswas from $2003[15,16]$. Subcutaneous infiltration with local anesthetic bupivacaine and the effect upon hemodynamics is for the first time investigated in the study of Hillman et al from 1987 [17] which demonstrated the blocking effect of the nerve endings for skin, subcutaneous tissue, muscles and periosteum of external part of the scalp.

Several possible mechanisms are suggested for the analgesic effect of the bupivacaine as local anesthetic. The studies of Pinosky from 1996 [3] and Hillman from 1987 [17] describe the membrane stabilizing effect occurring on smooth vascular musculature or sympathetic nerves. 
The prolonged activity of the bupivacaine is due to the decreasing of the absorption and the increasing of the capillary permeability. Since the scalp is highly vascularized we did not use vasoconstrictor as adjunct to the local anesthetic just to disable the possibility for accidental intravascular injection and absorption in circulation leading to hypertension and tachycardia.

The study of Kinna G Shah et al. from 2014 [18] investigated the changes of the hemodynamic parameters in patients with craniotomy who were divided in three groups depending on the substance which was infiltrated before the pin fixation and the scalp incision: the group with saline, the group with bupivacaine and the group with tramadol. The results demonstrated significantly higher values of the hemodynamic parameters in the group of saline.

Likewise, in the study of Mohammadin from 2003 [19] it is found that the biggest significant difference $p=0.03$ using bupivacaine $0.25 \%$ is achieved through the heart rate changes. The study of Bloomfield from 1998 [15] reported a lacking hemodynamic response as result of the skin incision with $0.5 \%$ bupivacaine adding adrenaline as adjunct.

In the study of Bithal from 2007 [13] 44 patients with cervical discectomy were followed. In their skull were inserted cranial pins for fixation. In the group without locally infiltrated anesthetic changes in the hemodynamic parameters it occurred with significant difference compared to the other group. He also found that the bispectral index increased significantly in the group without local anesthetic.

These results correspond to the results in our study. We used $0.25 \%$ bupivacaine as anesthetic and it was locally infiltrated at the place of the cranial pin insertion and the skin scalp incision. We selected bupivacaine because of its longer activity and safety for vascularized scalp tissue. We investigated the effect upon hemodynamics and awareness using the value of the bispectral index as measure of the anesthesia depth. Analyzing the results in both groups and comparing them, we found significant difference $p<0.05$ for all three parameters: MAP, HR and BIS index. The difference for the mean arterial pressure was statistically significant in all four time intervals $(\mathrm{t} 1, \mathrm{t} 2, \mathrm{t} 3$ and $\mathrm{t} 4)$, for the heart rate the significant difference was in time intervals $\mathrm{t} 1, \mathrm{t} 2$ and $\mathrm{t} 3$ and for the BIS index the significant difference was in $\mathrm{t} 2, \mathrm{t} 3$ and $\mathrm{t} 4$.

Comparing the parameters changes in all four time intervals related to the initial time t $0,2-5 \mathrm{~min}$ before the pin insertion we found significant difference in Group S where patients were locally infiltrated with saline.

Also, our hypothesis was confirmed by monitoring the depth of the anesthesia (bispectral monitoring) following the BIS index which has shown big fluctuations using saline. With further analysis it was proven that precisely, the variable BIS index contributes the most to the total significance in Group S.

\section{CONCLUSION}

Scalp infiltration with local anesthetic bupivacaine results with stable hemodynamic condition and normal intracranial pressure during the painful procedures in craniotomy as pin insertion and skin incision. This condition is achieved through maintaining continuous appropriate anesthesia depth without increasing the nervous cell metabolism and without increasing the perfusion in the rigid cranial vault.

\section{REFERENCES}

1. Matakas F, Von Waechter R, Knüpling R, Potolicchio SJ Jr. Increase in cerebral perfusion pressure by arterial hypertension in brain swelling. A mathematical model of the volume-pressure relationship. J Neurosurg 1975;42:282-9

2. Palmer JD, Sparrow OC, Iannotti F. Postoperative hematoma: A 5-year survey and identification of avoidable risk factors. Neurosurgery 1994;35:1061-4.

3. Pinosky ML, Fishman RL, Reeves ST, Harvey SC, Patel S, Palesch Y, et al. The effect of bupivacaine skull block on the hemodynamic response to craniotomy. Anesth Analg 1996;83:1256-61.

4. Colley RS, Dunn . Prevention of blood pressure response to skull pin head holder by local anesthesia. Anesth Analg 1979; 58:241-243

5. Levin R, Hesselvik JF, Kourtopoulos H, Vavruch L Local anaesthesia prevents hypertension following application of the Mayfield skull pin head holder. Acta Anaesthesiol Scand 1989; 33:277-279

6. Sigl JC, Chamoun NG. An introduction to bispectral analysis for the electroencephalogram. J Clin Monit 1994; 10:392-404 
7. Struys M, Versichelen L, Mortier E, Ryckaert D, De Mey JC, De Deyne C, Rolly G. Comparison of spontaneous frontal EMG, EEG, power spectrum, and bispectral index to monitor propofol drug effect and emergence. Acta Anaesthesiol Scand 1998; 42:628-636

8. Doi M, Gajraj RJ, Mantzarids H, Kenny GN. Relationship between calculated blood concentration of propofol and electrophysiological variables during emergence from anaesthesia: a comparison of bispectral, spectral edge frequency, median frequency, and auditory evoked potential index. Br J Anaesth 1997; 78:180-184

9. Johansen JW, Sebel PS. Development and clinical application of electroencephalographic bispectrum monitoring. Anesthesiology 2000; 93:1336-1344

10. Ekman A, Lindholm ML, Lennmarken C, Sandin R. Reduction in the incidence of awareness using BIS monitoring. Acta Anaesthesiol Scand 2004; 48:20-26

11. Myles PS, Leslie K, McNeil J, Forbes A, Chan MTV. Bispectral index monitoring to prevent awareness during anaesthesia: the B-aware randomized controlled trial. Lancet 2004; 363:1753-1763

12. Mathieu D, Beaudry M, Martin R, McLelland H, Robert B, Kenny B. Effect of local anesthetic agent bupivacaine prior to application of the skull pin holder for craniotomies. J Neurosurg 2003; 98:1194-1197

13. Bithal PK, Pandia MP, Chouhan RS, Sharma $\mathrm{D}$, Bhagat $\mathrm{H}$, Dash HH, et al. Hemodynamic and bispectral index changes following skull pin attachment with and without local anesthetic infiltration of the scalp. J Anesth 2007;21:442-4

14. Bala I, Gupta B, Bhardwajal, Ghai B, and Khosla VK.2006: Effect of scalp block on post op pain relief in craniotomy patients. Anesth.Intensive Care, 34(2)224-7.

15. Bloomfield EL, Schubert A, Secic M, Barnett G, Shutway F, Ebrahim ZY. The influence of scalp infiltration with bupivacaine on haemodynamic and postoperative pain in adult patients undergoing craniotomy.AnesthAnalg 1998. Sep; 87(3):579-82

16. Biswas, Binay K.; Bithal, Parmod K.Preincision $0.25 \%$ Bupivacaine Scalp Infiltration and Post craniotomy Pain. Journal of Neurosurgical Anesthesiology 2003; July; 15(3):234-2

17. Hillman DR, Rung G W, Thompson W R, Davis N J.The effect of Bupivacaine scalp infiltration on the haemodynamic response to craniotomy under general anaesthesia. Anaesthesiology 1987. 67:1001-4

18. Shah G. K, ShahC. B , Prajapati D. Skull pins and scalp incision infilteration with $\mathrm{Bu}-$ pivacaine Hydrochloride and Tramadol hydrochloride -- effects on the haemodynamic response in craniotomy under general anesthesia. International Journal of Advanced Research 2014; 2(9): 590-597

19. Mohammadi SS, Shahbazian E, Shoeibi G, Almassi F. 2009.Effect of scalp infiltration with Bupivacaine on early haemodynamic responses during craniotomy under general anesthesia .Pak J Biol Sci. Apr 1; 12(7):603-6. 


\title{
ПРОМЕНИ ВО БИСПЕКТРАЛНИОТ ИНДЕКС И ХЕМОДИНАМИКАТА ПРИ ПИН ИНСЕРЦИЈА КАЈ КРАНИОТОМИИ - ЕФЕКТ НА ЛОКАЛНО ИНФИЛТРИРАН БУПИВАКАИН
}

\author{
Весна Дурнев ${ }^{1}$, Марија Шолјакова ${ }^{1}$, Венко Филипче ${ }^{2}$, \\ Маја Мојсова Мијовска ${ }^{1}$, Марина Темелковска Стевановска ${ }^{1}$ \\ ${ }^{1}$ Универзитетска клиника за трауматологија, ортопедија, анестезија, реанимација, \\ интензивна нега и за итни случаи, Медицински факултет, \\ Универзитет „Св. Кирил и Методиј“, Скопје, Р. Македонија \\ ${ }^{2}$ Универзитетската клиника за неврохирургија, Медицински факултет, \\ Универзитет „Св Кирил и Методиј“, Скопје, Р. Македонија
}

\section{Резиме}

Вовед: Поставување на кранијални пинови е метода за стабилизација на главата. Заедно со кожната инцизија на скалпот спаѓа во група на јаки ноцицептивни стимулуси кои се асоцорани со будење и нагло зголемување на крвниот притисок кое води до рапидно зголемување на интракранијалниот притисок. Целта на ова испитување е да се испита супериорноста на локално инфилтриран анестетик бупивакаин на местото на инцизија на скалпот и инсерција на черепните пинови кај пациенти со краниотомија подложени на општа анестезија.

Методи: Беа вклучени триесет пациенти од двата пола, на возраст од 24-72 години со АСА статус 1 и 2 и поделени во две групи секоја составена од 15 пациенти, група Б (бупивакаин група) и група $\Phi$ (физиолошки раствор група). Се следеа промените во вредностите на биспектралниот индекс, средниот артериски притисок и срцевата фреквенција пред инсерција на пиновите (т0), т1 (2 мин после пин инсерција), и последователни регуларни итервали (т2 во 5 минута, т3 во 10 минута и т4 во 15 минута).

Резултат: Се доби сигнификатна разлика $p<0.05$ во групата $Ф$ за сите три следени параметри: крвниот притисок, пулсот и биспектралниот индекс. Разликата е во сите четири времиња во однос на почетното време пред поставување на пиновите т0. Со понатамошна анализа се докажа дека варијаблата БИС најмногу допринесува во вкупната сигнификантност во Групата Ф.

Заклучок: За време на болни процедури при краниотомија инфилтрацијата на скалпот со локален анестетик бупивакаин резултира со стабилни хемодинамски параметри и стабилен интракранијален притисок.

Клучни зборови: кранијални пинови, локална инфилтративна анестезија, хемодинамика, биспектрален индекс, бупивакаин 